\title{
You are too brash if you ignore the rash
}

\author{
Madan Raj Aryal, ${ }_{1}^{1}$ Paras Karmacharya ${ }_{1}^{2}$ Naresh Bhandari, ${ }^{3}$ Anup Subedee ${ }^{4}$
}

1 Department of Internal Medicine, Reading Health System, West Reading, Pennsylvania, USA 2Department of Internal Medicine, Reading Health System, Wyomissing, Pennsylvania, USA ${ }^{3}$ Department of Internal Medicine, St. Agnes Hospital, Baltimore, Marylaand, USA ${ }^{4}$ Department of Infectious Disease, Tulane university, New Orleans, Louisiana, USA

\section{Correspondence to}

Dr Paras Karmacharya, paraskarmacharya@gmail.com
To cite: Aryal MR, Karmacharya P, Bhandari N, et al. BMJ Case Rep Published online: [please include Day Month Year] doi:10.1136/bcr-2013200506

\section{DESCRIPTION}

A 42-year-old homosexual man with HIV AIDS presented with headache, neck pain and a new bilateral palmoplantar rash for 2 weeks. On examination, he had a temperature of $39.6^{\circ} \mathrm{C}$ and neck stiffness was noted. Maculopapular rash with some scaling was present on bilateral distal extremities, especially in the palmar (figure 1) and plantar surfaces (figure 2). Genital lesions were absent. A complete blood count was unremarkable. CD4 cell count was $287 / \mu \mathrm{L}$. An MRI of the brain was unremarkable. Cerebrospinal fluid (CSF) analysis showed white cell count of $141 / \mathrm{mm}^{3}$ with lymphocytic predominance, protein $230 \mathrm{mg} / \mathrm{dL}$ and glucose $14 \mathrm{mg} / \mathrm{dL}$. Gram-stain, acid-fast stain, India ink stain, cryptococcal antigen, PCR for herpes simplex and toxoplasma antibody tests in CSF were all negative. Given the palmoplantar rash and the CSF fluid findings, serological tests for syphilis were also ordered. Serum rapid plasma reagin was reactive at titre 1:1024 and florescent treponemal antibody-absorption(FTA-ABS) was positive. Venereal disease research laboratory (VDRL) in CSF was reactive (1:32). The patient was started on a 2-week course of intravenous penicillin and had rapid symptomatic improvement.

Neurosyphilis may present with widely variable presentations in different stages of syphilis and can be missed if non-neurological symptoms or signs of syphilis, 'the great impostor', are not recognised. It is important to recognise that meningitis can appear in early secondary syphilis, as it did in our case, as the earliest presentation of neurosyphilis. ${ }^{1}$

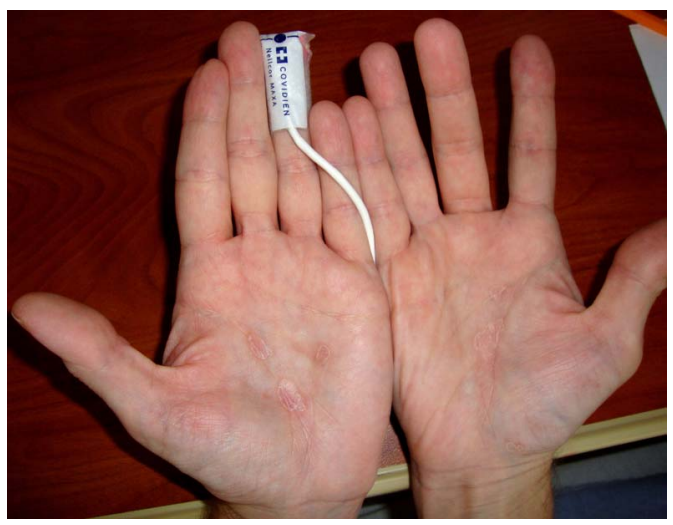

Figure 1 Non-pruritic maculopapular palmar rash in a patient with syphilitic meningitis.

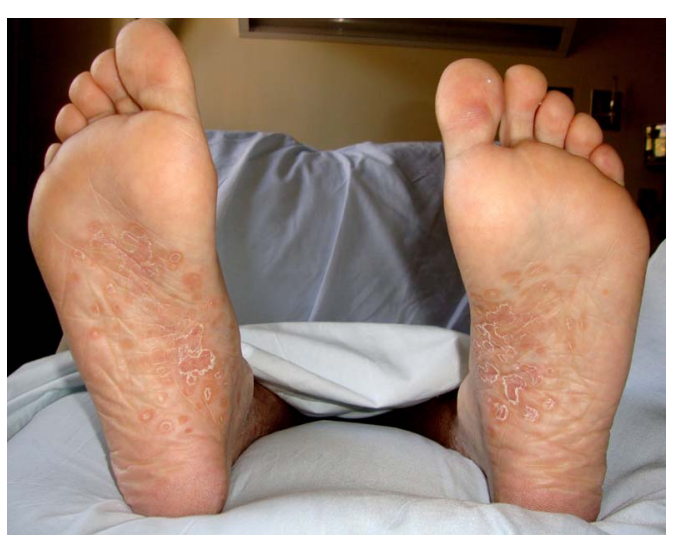

Figure 2 Non-pruritic maculopapular plantar rash in a patient presenting with syphilitic meningitis.

Diagnosis is confirmed with demonstration of VDRL or FTA-ABS titre in CSF.

\section{Learning points}

- It is important to recognise that meningitis can appear in early secondary syphilis, as it did in our case, as the earliest presentation of neurosyphilis.

- A high index of suspicion as well as correlation with non-neurological symptoms or signs such as palmoplantar rash or epitrochlear lymph node enlargement which can be highly suggestive of syphilis would facilitate early diagnosis and treatment.

- Diagnosis can be confirmed with demonstration of venereal disease research laboratory or florescent treponemal antibody-absorption titre in cerebrospinal fluid.

Contributors MRA and AS designed the case study and provided the logistics. PK and NB provided subsequent manuscript edits.

Competing interests None.

Patient consent Obtained.

Provenance and peer review Not commissioned; externally peer reviewed.

\section{REFERENCE}

1 Lichten GD, Pomeranz JR, Chester CS, et al. Secondary syphilis with acute meningitis and quadriparesis. J Am Acad Dermatol 1980;2:388-92. 
Copyright 2013 BMJ Publishing Group. All rights reserved. For permission to reuse any of this content visit http://group.bmj.com/group/rights-licensing/permissions.

BMJ Case Report Fellows may re-use this article for personal use and teaching without any further permission.

Become a Fellow of BMJ Case Reports today and you can:

- Submit as many cases as you like

- Enjoy fast sympathetic peer review and rapid publication of accepted articles

- Access all the published articles

- Re-use any of the published material for personal use and teaching without further permission

For information on Institutional Fellowships contact consortiasales@bmjgroup.com

Visit casereports.bmj.com for more articles like this and to become a Fellow 